\title{
Concept Mapping Strategy through Hybrid Flexible Course: Its Significance toward Student Achievement
}

\author{
${ }^{1}$ Kiswati, ${ }^{2}$ Rosi Anjarwati \\ ${ }^{1}$ MAN 5 Jombang, Indonesia \\ ${ }^{2}$ English Department, STKIP PGRI Jombang, Indonesia \\ Corresponding Author: rosi.stkipjb@gmail.com
}

\begin{abstract}
The pandemic era pushed teachers to switch their teaching methods into online learning. The concept mapping strategy was one of the most effective teaching strategies for teaching English in face-o face mode. Is the concept mapping strategy still effective in online learning mode? This study utilized a quantitative approach to compare the use of concept mapping strategy and conventional strategy. Both classes did the instruction through hybrid flexible course. To obtain the data, test and observation were used. ANCOVA was performed to analyze the data to get the specific data concern to the effect of the strategy to the student grade. The findings showed that in the hybrid flexible course, concept mapping strategy did not impact the students' achievement, but from the observation, it did impact the students' motivation and activity during the instruction. It can be concluded that there is no significant difference of using concept mapping strategy and conventional strategy through hybrid flexible course.
\end{abstract}

Keywords: concept mapping strategy, hybrid flexible course, student achievement ABSTRAK
Era pandemic mendorong para guru unruk mengalihkan metode pengajarannya menjadi
pembelajaran online. Strategi pemetaan konsep adalah salah satu strategi pengajaran yang paling
efektif untuk mengajar Bahasa Inggris dalam metode tatap muka. Apakah strategi pementaan
konsep masih efektif dalam mode pembelajaran online? Penelitian ini menggunakan pendekatan
kuantitatif untuk membandingkan penggunaan strategi pemetaan konsep dan strategi
konvensional. Kedua kelas melakukan pengajaran secara hybrid yang fleksibel. Untuk
memperoleh data digunakan tes dan observasi. ANCOVA dilakukan untuk menganalisis data
untuk mendapatkan data spesifik yang berkaitan dengan pengaruh strategi terhadap nilai siswa.
Hasil penelitian menunjukkan bahwa pada mata kuliah hybrid, strategi pemetaan konsep tidak
berdampak pada prestasi belajar siswa, tetapi dari pengamatan, hal itu berdampak pada motivasi
dan aktivitas siswa selama pembelajaran. Dapat disimpulkan bahwa tidak ada perbedaan yang
signifikan antara penggunaan strategi pemetaan konsep dan strategi konvensional melalui mata
kuliah hybrid yg fleksibel.
Kata kunci: strategi pemetaan konsep, mata kuliah hybrid yang fleksibel, prestasi belajar siswa

\begin{tabular}{|l|l|l|}
\hline Received: January 19, 2022 & Accepted: February 19, 2022 & Published: February 23, 2022
\end{tabular} How to cite:

Kiswati, K. \& Anjarwati, R. (2022). Concept mapping strategy through hybrid flexible course: its significance toward student achievement. English Learning Innovation, 3(1), 70-84. https://doi.org/10.22219/englie.v3i1.19797 


\section{INTRODUCTION}

Teaching English has played a significant role in addressing the issues of educational development in Indonesia. On behalf of the government, Ministry of Education, Ministry of Religious Affairs, and other educational experts who oversee the establishing English curriculum in Aliyah, senior high school level under Ministry of Religious Affairs, have decided the goal of learning English, that is, communication ability both oral and written. Harmer (2007, p. 165) divided English skills into two; receptive skills, i.e., reading and listening, and productive skills, i.e., speaking and writing. In reading, students need to comprehend either the extrinsic or intrinsic message of the passage. Nuttal (1996, p. 3) mentioned the reading purposes done by the readers due to their curiosity of facts, ideas, joy, and what the writers want to deliver the message of the passage. In the same vein, Liepzig (2021, p. 1) said that reading activity is not merely reading a text but also comprehend the passage. In Indonesia teaching reading is categorized as teaching reading comprehension (Cahyono \& Widiati, 2006).

These recent years, online learning became very popular all over the world, including Indonesia. Pandemic forced the government to switch face to face with online learning. The teachers had to adjust to the situation. The students had to do the instruction at their house. The parents had to manage the time to be with their children and to help the children to solve the school problems, such as the gadget, the internet connection, the nutrition and also the comfortable place to study at home. The teachers who usually used teaching and learning strategy on face-to-face meetings had to change the many online strategies to their classes.

The world bank (2020) stated that different learning system had been implemented by several countries. They made the policy of the learning system based on the situation in their country. Finland had implemented distance learning, a digital learning environment, and independent learning. The ministry of education and science of Bulgaria had launched elearning system (Rasmitalida, 2020). While in Indonesia, The ministry of religious affairs also launched e-learning system that we called e-learning madrasah.

Another problem about online learning happened to the students from rural areas. Dube (2020) conducted an action research by applying online learning method to his students in rural areas in Africa. The result showed that the students from rural area had more complex problems in doing online learning than the students who came from cities. It happened because the lack of resources and also motivation to study. Parkes et al (2015) did a qualitative research to know 
the problems happening when applying online learning in remote area. They found that the students had some problems in doing online learning. They are the lack of signal, the far distance to get to the good facility needed by online learning and the lack of IT person. These kinds of fact also happened to the students of MAN 5 Jombang, the setting of this research. MAN 5 Jombang that is located in the rural area also has the same problems in doing online learning due to some reasons, such as the signal, the facilities and the human resources.

E-learning Madrasah platform (a platform developed by school under the Religion Ministry) has actually the same facilities with other learning platforms like Google Classroom, Edmodo, Moodle, etc. All madrasah teachers had to use the platform in their online classes. Some problems then came up. The students who were from the rural area got difficulty with the signal, the students who came from poor family got difficulty with the payment to buy the data and the students who had low competence in using technology also had problem on online learning.

Furthermore, to solve the problem, some teachers implemented hybrid learning that combined between online and offline learning. They also used the old method that they usually used in their face to face class. Some researches had been conducted to help improve the courses and identify factors that affect the learning performance.

The researcher attempts to improve the student achievement in learning narrative text by conducting hybrid flexible course with a teaching strategy, namely Concept Mapping Strategy. This teaching strategy is widely used to ease students comprehending the materials, and it is also known as Semantic Mapping, that is, a strategy that uses text structure and visual text representative. This teaching strategy is basically from Novak Technique which is developed in Cornel University in 1970. Novak and Gowin (as cited in (Dolehanty, 2021) explained that for a meaningful learning, individuals must choose to relate new knowledge to knowledge of concepts and prepositions they already know. He added that concept mapping is a tool to hone reading ability.

Thus far, a number of studies have attempted to prove concept mapping as a valuable teaching strategy in the learning process. For example, Syarif (2003) used concept mapping to increase students' reading ability at the primary level. They found that this teaching strategy is effective for improving students' reading ability. Balokis et al (2021) utilized concept mapping to increase students' achievement and conceptual understanding in chemical equilibrium problems. Thus, the concept mapping strategy proved a critical view in a successive learning process to motivate students learning participation which can improve their achievements. 
Although the convenience of hybrid learning is worthy of consideration, student achievement should put on the primary part. Amin and Li (2021); Daymount and Blau (2011); Yensy (2020) find that online learning doesn't differ significantly compared to face to face learning. This fact brought to curiosity for the researcher to do this research.

The aim of the study was to examine the effects of concept mapping strategy through hybrid flexible course on students' achievement in MAN 5 Jombang.

\section{Research Hypotheses}

Ho: There is no difference in students' achievement between students who are taught using concept mapping strategy through hybrid learning and those who are not.

Hi: There is a significance difference in students' achievement between students who are taught using concept mapping strategy through hybrid learning and those who are not.

\section{METHOD}

The study utilized a quantitative research methodology. Gay, Mills \& Airisian (2012) stated that the quantitative method was used to describe, analyze, and predict certain phenomena. Interpreting statistical procedures may provide information regarding research hypotheses as well as solutions to problems. Researchers may also suggest next-step design to investigate another dimension of the problem. Creswell (2012) also stated that quantitative data may explain how learning strategy influenced student achievement.

\section{Research Design}

This study is an experimental quasi research using a factorial of non-equivalent pre-test post-test control group design. The experimental class was taught by applying concept mapping strategy in online and face to face mode, while the control class was taught by applying conventional strategy. Conventional strategy here refers to lecturing strategy which means that the teacher explains the material and then give the students worksheet. Both classes were taught by hybrid flexible course that used by the teachers in the school. The researcher combined the e-learning madrasah platform and WhatsApp application. Each group had heterogeneous ability in English (low, medium, high).

\section{Research Sample}

The participant of the study were two classes selected by using cluster random sampling from 6 classes at MAN 5 Jombang (Senior High School). The samples were then divided into two groups, experimental and control (Cohen et al., 2005). All the participants were from eleventh grade. Their age was between 15 to 17 years old. The 
experimental group consisted of 19 students, while the control group consisted of 18 students.

\section{Research Instrument and procedures}

The instruments of this study were a student activity observation sheet and a reading comprehension test that is divided into pretest-posttest. The observation sheet was adapted from Al-Jafr (2021). The pretest posttest was developed by the researcher based on the indicators of reading comprehension from Brown (2003, p. 206). The item of pretest posttest consists of seven items with the same questions. The items consisted of the main idea, phrases in context, inference (implied detail), grammatical features, specifically stated detail, and unstated detail.

All items have been tested to examine the validity and reliability of a class outside the experiment and control groups. There were 12 students who did the try out. To confirm the validity and reliability of the test, the researcher applied a product-moment correlation and alpha coefficient test (Cronbach, n.d.) First step, the researcher did was testing the validity. The result showed that all items were valid. Then we continue to test the reliability of the pretest posttest. The result of the validity and reliability of the test is shown in Table 1.

Table 1. The Validity and Reliability of Instrument Test

\begin{tabular}{cccccccc}
\hline Test & \multicolumn{10}{c}{ Item } \\
\hline Validity & 1 & 2 & 3 & 4 & 5 & 6 & 7 \\
$\left(\mathrm{r}_{\mathrm{xy}}\right)$ & 0.89 & 0.83 & 0.89 & 0.79 & 0.88 & 0.92 & 0.93 \\
Reliable & & & & 0.94 & & & \\
\hline
\end{tabular}

Based on the table, it can be concluded that all the items tested are significantly valid at the levels 0,01 and 0,05 because all items significance was above 0.05 . It was found that the pretest posttest reliability is significant because the Cronbach's Alpha was more than 0.60 as the medium as well.

\section{Data Analysis}

Two analysis techniques of data are applied in this study: descriptive statistical analysis and inferential statistical analysis.

Descriptive statistical analysis was used to analyze the effectiveness of concept mapping strategy through hybrid learning on the topic of narrative. The data were collected student 
responses data, student activity data, and students learning outcome data. Student responses are called to be positive if more than $80 \%$ of students choose the positive category for each aspect of the questionnaire form. Student activities are called to be effective if the percentage of every aspect observed at each meeting is in the ideal time range of student activity. Moreover, the student learning outcome data will be analyzed descriptively to describe the student learning outcomes based on the test implemented. Students will be called master the material if they get scores of at least 70 with a maximum score of 100 .

Inferential statistical analysis is aimed to see the differences in student achievement following concept mapping strategy or conventional strategy through hybrid learning on narrative material. Pretest posttest data were analyzed by the inferential statistics of ANCOVA. The researcher choose analysis of covariance to test the main and interaction effects of categorical variables on a continuous dependent variable, controlling for the effects of selected other continuous variables, which co-vary with the dependent. To perform ANCOVA, it was necessary to get good assumptions regarding normality, homogeneity, the equation of variance, and the equation of regression lines. Kolmogorov Smirnov Test was used to determine the satisfy of the assumption. Based on the normality test, it was found that the assumption of significance was 0.200 bigger than 0.05 so that can be concluded that the test distribution was normal. The homogeneity test of variance showed a significance value of 0.616 , bigger than 0.05. It can be concluded that the data had the same (homogeneous) variance. The value of deviation from linearity was 0.708 showed that the data was linear because it was bigger than 0.05. the last analysis before going to ANCOVA was the value of regression slope. It was found the value of 0.680 showed that the data had the same (homogeneous). After all, conditions had been done, the ANCOVA is ready to apply. Descriptive statistical analysis was used to compare the average score of the pretest and posttest for the experimental and control group.

Regarding the percentage of student mastery of learning on table 2 shows that there are 14 students in the experimental class who pass the passing grade, with a minimum passing grade $=70$. Thus, the percentage of student mastery is $74 \%$. Compared to the control class, which had 16 out of 18 students who pass the passing grade; we can conclude that the control class has a higher score than the experimental class.

During four meetings at hybrid learning using concept mapping strategy in the experimental class and conventional strategy in the control class, the researcher set two meetings of online learning and two meetings face to face learning in the classroom. In online learning, both classes showed that the student activity was not very high. It was proved by the 
number of the students who asked questions and answered questions from the teacher are less than 5 students. In face to face class, it was found that the students were active in the experimental class. It was proved by almost all students were active in doing the instruction. Only two students were sleeping during the instruction. The other students looked happy to fill the concept mapping given by the teacher and tried to understand the text by answering all the questions in the student's worksheet. However, in the conventional class, more students did irrelevant activities, such as sleeping, playing, and chatting with their friends without paying attention to the task given by the teacher. Seemed that they felt bored with the activity. Thus, the experimental class met the effective category, while the control class did not meet the effective category.

The result of the questionnaire showed that the number student responses to the learning response in the positive category in the experimental class was high. There were 17 out of 19 $(89 \%)$ students who response items in the positive category. In conclusion, the student's responses are positive. Therefore, the control class showed a lower positive response than the experimental class. Only 8 students (44\%) out of 18 students responded positively to the learning activity they have done during the narrative class.

In brief, the result of descriptive statistical data analysis was different between the student achievement, the activity, and the response from the students. To get more specific data, the researcher then did the inferential statistical data analysis.

Inferential statistical analysis is aimed to see the differences in student achievement following concept mapping strategy or conventional strategy through hybrid learning on narrative material. Pretest posttest data were analyzed by the inferential statistics of ANCOVA. The researcher choose analysis of covariance to test the main and interaction effects of categorical variables on a continuous dependent variable, controlling for the effects of selected other continuous variables, which co-vary with the dependent. To perform ANCOVA, it was necessary to get good assumptions regarding normality, homogeneity, the equation of variance, and the equation of regression lines. Kolmogorov Smirnov Test was used to determine the satisfy of the assumption. Based on the normality test, it was found that the assumption of significance was 0.200 bigger than 0.05 so that can be concluded that the test distribution was normal. The homogeneity test of variance showed a significance value of 0.616 , bigger than 0.05. It can be concluded that the data had the same (homogeneous) variance. The value of deviation from linearity was 0.708 showed that the data was linear because it was bigger than 0.05. the last analysis before going to ANCOVA was the value of regression slope. It was found 
the value of 0.680 showed that the data had the same (homogeneous). After all, conditions had been done, the ANCOVA is ready to apply. Descriptive statistical analysis was used to compare the average score of the pretest and posttest for the experimental and control group.

\section{FINDINGS AND DISCUSSION}

This study employed two data analysis. Descriptive data analysis and inferential statistical data analysis obtained during the research process. Statistics Package for Social Science (SPSS 23) was used to analyze all data. The result are presented as follows:

\section{Findings}

\section{The Result of descriptive Statistical Data Analysis}

Analysis of data obtained on the implementation of concept mapping strategy and conventional strategy through hybrid learning is as follows:

Table 2.Comparison of Student Achievement in Experimental and Control Classes

\begin{tabular}{lcc}
\hline \multicolumn{1}{c}{ Information } & Experimental Class & Control Class \\
\hline Average of student achievement & 76.6 & 82.5 \\
Percentage of students who mastered & & $84 \%$ \\
learning & $74 \%$ & \\
\hline
\end{tabular}

Regarding the percentage of student mastery of learning on table 2 shows that there are 14 students in the experimental class who pass the passing grade, with a minimum passing grade $=70$. Thus, the percentage of student mastery is $74 \%$. Compared to the control class, which had 16 out of 18 students who pass the passing grade; we can conclude that the control class has a higher score than the experimental class.

During four meetings at hybrid learning using concept mapping strategy in the experimental class and conventional strategy in the control class, the researcher set two meetings of online learning and two meetings face to face learning in the classroom. In online learning, both classes showed that the student activity was not very high. It was proved by the number of the students who asked questions and answered questions from the teacher are less than 5 students. In face to face class, it was found that the students were active in the experimental class. It was proved by almost all students were active in doing the instruction. Only two students were sleeping during the instruction. The other students looked happy to fill the concept mapping given by the teacher and tried to understand the text by answering all the questions in the student's worksheet. However, in the conventional class, more students did 
irrelevant activities, such as sleeping, playing, and chatting with their friends without paying attention to the task given by the teacher. Seemed that they felt bored with the activity. Thus, the experimental class met the effective category, while the control class did not meet the effective category.

The result of the questionnaire showed that the number student responses to the learning response in the positive category in the experimental class was high. There were 17 out of 19 $(89 \%)$ students who response items in the positive category. In conclusion, the student's responses are positive. Therefore, the control class showed a lower positive response than the experimental class. Only 8 students (44\%) out of 18 students responded positively to the learning activity they have done during the narrative class.

In brief, the result of descriptive statistical data analysis was different between the student achievement, the activity, and the response from the students. To get more specific data, the researcher then did the inferential statistical data analysis.

\section{The Result of Inferential Statistical Data Analysis}

Before statistical tests, some tests were performed to get satisfy assumptions regarding normality, homogeneity, and linearity of the data. They are important for inferential statistics. Normality test was performed to determine whether the data followed normal distribution. This is important to generalize the results of the analysis of sample data. The data reveals:

Table 3. The Normality Test of the Experimental Class and the Control Class by Using Kolmogorov Smirnov Test

\begin{tabular}{c|c|c|c|}
\hline Kolmogorov Smirnov & Statistic & Df & Sig. \\
\hline 0.120 & 36 & 0.200 \\
\hline
\end{tabular}

a. Test distribution is normal

b. Lilliefors Significance Correction

As shown in Table 3, the Kolmogorov Smirnov test found that the significance value is 0.200 . This is more than 0.05 so that we can conclude the test distribution is normal.

Homogeneity test was performed to determine whether the data had homogeneity of variance. The data reveals:

Table 4. Levine Test Result for Homogeneity if Variance

\begin{tabular}{cccc}
\hline Levine Statistic & $d f 1$ & $d f 2$ & Sig. \\
\hline Englie: English Learning Innovation, 3(1), $70-84$ &
\end{tabular}


The data shown in table 4, the Levine test resulted the significant value 0.616 is bigger than 0.05. It is concluded that Ho is accepted, meaning that the data had homogeneity of variance. Since the data had passed the normality and homogeneity test, the researcher continued to test the linearity of the data.

The linearity test determines whether the linear model obtained can be applied to show the effect on student achievement. The data obtained results are as follows:

Table 5. Independence Test of Experimental Class and Control Class Data

\begin{tabular}{cccccc}
\hline & $\begin{array}{c}\text { Sum of } \\
\text { Squares }\end{array}$ & Df & Mean Square & \multirow{F}{*}{ Sig. } \\
\hline Between group & 3646.134 & 11 & 331.467 & 2.723 & 0.018 \\
Linearity & 2782.959 & 1 & 2782.959 & 22.863 & 0.000 \\
Deviation from linearity & 863.175 & 10 & 86.317 & 0.709 & 0.708 \\
Within groups & 3043.056 & 25 & & & \\
Total & 6689.189 & 36 & & & \\
\hline R Squared & & & & &
\end{tabular}

R Squared $=0.416$

From the table above, it was found that the deviation from linearity is 0.708 , higher than 0.05 . it can be concluded that the data is linear.

The last step before going to ANCOVA was counting the homogeneity or regression slope. After using SPSS, then it was found the data as below:

Table 6. Test of Homogeneity of Regression Slope

\begin{tabular}{c|c|c|c|c|c}
\hline \multirow{2}{*}{ Source } & $\begin{array}{c}\text { Type III Sum of } \\
\text { Squares }\end{array}$ & Df & Mean Square & F & Sig. \\
\hline Metode & 19.759 & 1 & 19.759 & 0.173 & 0.680 \\
\hline
\end{tabular}

a. $\quad$ R Squared $=0.419$ (Adjusted R Squared $=0.385)$

The table above shows that the value of method significance was 0.680 which is more than 0.05 . That led to the conclusion that there was positive homogeneity of regression slope.

Furthermore, the ANCOVA test was conducted to see whether the student achievement in the experimental and control class were different after being given concept mapping strategy through hybrid learning and conventional lesson. The data analysis result are as follows: 
Table 7. ANCOVA Test of Experiment and Control Class Data Test of Between-Subject Effects

Dependent Variable: Student Achievement

\begin{tabular}{lcccccc}
\hline Source & $\begin{array}{c}\text { Type III Sum } \\
\text { of Squares }\end{array}$ & $d f$ & $\begin{array}{c}\text { Mean } \\
\text { Square }\end{array}$ & $\boldsymbol{F}$ & Sig. & $\begin{array}{c}\text { Partial } \\
\text { Eta Squared }\end{array}$ \\
\hline Corrected & $2802718^{\mathrm{a}}$ & 2 & 1401.359 & 12.260 & 0.000 & 0.419 \\
Model & & & & & & \\
Intercept & 10586.594 & 1 & 10586.594 & 92.615 & 0.000 & 0.731 \\
Metode & 19.759 & 1 & 19.759 & 0.173 & 0.680 & 0.005 \\
Kovariat & 2478.660 & 1 & 2478.660 & 21.684 & 0.000 & 0.389 \\
Error & 3886.471 & 34 & 114.308 & & & \\
Total & 240300.000 & 37 & & & & \\
Corrected & 6689.189 & 36 & & & & \\
Total & & & & & & \\
\hline
\end{tabular}

Based on the Tests of Between-Subjects Effects table shown, it can be seen that the significance of independent variable (method) show the value of 0.680. Since Sig. value > sifnificant $(\alpha)=0.05$, it can be concluded that $\mathrm{H}_{\mathrm{o}}$ is accepted. In other words, there is no differences in learning outcomes between students taught by concept mapping strategies and students taught with conventional learning strategies. From Eta Squared value it was found that there is significant effect of pre-test to the student achievement compared to learning strategy.

\section{Discussion}

Based on the descriptive analysis, it was found that the average score of the experimental class was lower than those who were in control class. It can be predicted that the cause of the differences was from the basic knowledge of the respondent or the learning and teaching strategy given. Marashi \& Kangani (2018) did the research on concept mapping strategy on narrative and descriptive. He found that this strategy was very effective to inactivate the students and manage the class successfully. Moreover, Sieben et.al (2021) yielded supportive evidence that concept mapping could help the medical students to write the reflection in reflective concept.

Furthermore, from the observation done during the instruction, the researcher got the data that the students' motivation in learning the material was high. The evidence of this statement 
was more than $80 \%$ of students were very active in doing the instruction during the learning process. They asked questions when they did not understand the material. They actively answered the questions from the teacher did the task in the worksheet in groups. It can be concluded that the concept mapping strategy is a great alternative strategy to make the students actively involved in the classroom.

Along with the positive result from the observation, the data gathered from the student responses about how's their feeling toward the use of mapping in their class was significantly effective. The students liked the idea of using maps in their English instruction. They felt that by using the map, they were helped to get the main idea and detail information of the narrative text. This finding also supported by the data from other researchers who conducted similar researches on concept mapping strategy. Torre et al (2007) stated that concept mapping offered opportunities to freely give the line of ideas. In line Torre, Al Jarf (2021) found that the mapping strategy was effective in enhancing reading tests. He added the information that the students' perspective toward mind mapping tool was positive in bring fun activity and helpful tool to comprehend the reading text.

The statements from the researchers above plus the evidence in this research showed that the concept mapping strategy is a great strategy to motivate the student to learn the material and to make the students actively involved in the instruction. This evidence lead to the suggestion of using this strategy to reading class. Nurhikmah (2011) stated that mapping strategy has some advantages. They are (a) a story map provides visuals and places the teaching focus on the structure of the story, (b) it is a practical way to help students organize story content into a coherent whole, (c) it is an effective strategy for exceptional and low achieving students, and (d) this concrete representations aid students visualizing the story.

In contrast with the descriptive analysis, the analysis of inferential statistical data showed different findings. After being analyzed with analysis of covariate (ANCOVA), it was found that the concept mapping strategy did not give improvement to the students' achievement. This fact happened due to some reasons. Although many researchers found the evidence that mapping strategy was effective in terms of improving the students' achievement. Vice versa, other research also proved the weaknesses of mapping strategy. Heeneman et.al (2019) stated that the effectiveness of using mapping strategy was not yet analyzed. It needs to be discussed more. In addition, the researcher also gave this mapping strategy through hybrid flexible course that never happened before. Concept mapping strategy was usually used in face to face meetings, not online. This fact may lead to the reason why the result of this study was not as 
the prediction. Concept mapping strategy may be effective in face to face meeting, but less effective to be used in online learning. It is showed that not all teaching strategies can be implemented on online platforms.

\section{CONCLUSION}

Based on the research result, it can be concluded that concept mapping strategy through the hybrid flexible course is not effective in the case of improving the learning outcome. However, this strategy is effective to improve the student motivation and activity during the instruction. In addition, the concept mapping strategy is effective to get a positive response from the students.

It is suggested to further studies in conducting similar research about concept mapping strategy and find the best way to use the strategy in the right context. Furthermore, experimental studies may be carried on to discover the dynamic of using technology that can determine the changes which will improve the learning outcome. It is also suggested the next researchers to choose the respondents of experimental group that has the same level as the control group in order to get the expected result.

\section{REFERENCES}

Al-Jarf, R. (2021). Teaching reading to EFL freshman students with Mind Mapping Software. SSRN Electronic Journal, 24.

Amin, R., \& Li, K. (2021). Should the graduate mathematics courses be offered online? Journal of Mathematics and Technology, 4(1).

Bakolis, A., Stamovlasis, D., \& Tsaparlis, G. (2021). Explicit teaching of problem categerization using concept mapping, and an exploratory study of its effect on student achievement and on conceptual understanding - The case of Chemical Equilibrium problems. In Chemistry Teacher International (pp. 1-16). De Gruyter.

Brown, H. D. (2003). Language assesment, principles and classroom practices. Longman.

Cahyono, B. Y., \& Widiati, U. (2006). The teaching of EFL reading. TEFLIN Journal, XVII(1).

Cohen, L., Manion, L., \& Morrison, K. (2005). Research methods in education (5th ed.). Taylor $\&$ Francis e-Library.

Cresswell, J. W. (2012). Educational research: Planning, conducting, and evaluating quantitative and qualitative research. Pearson.

Englie: English Learning Innovation, 3(1), 70-84 
Cronbach, L. J. (n.d.). Coefficient alpha and the internal Structure of test. Psyclzometrika, 16, 297-334.

Daymont, T., \& Blau, G. (2011). Student performance in online and traditional section of an undergraduate management course. Journal of Behavioral \& Applied Management, 9(3), 275-294.

Dolehanty, C. (2021). Concerpt Mapping and reading comprehension.

Dube, B. (2020). Rural online learning in the context of Covid-19 in South Africa: Evoking an inclusive education approach. Multidisciplinary Jourbal of Education Research, 10(2), $134-157$.

Harmer, J. (2007). The practice of English Language Teaching (4th ed.). Pearson Education Limited.

Heeneman, S., Driessen, E., Durning, S. J., \& Torre, D. (2019). Use of an E-Portofolio Mapping tool: Connecting experiences, analysis and action by learners. Perspect Med Educ, 8(3), 197-200.

How countries are using Edtech (Including online learning, radio, television, texting) to support access to remote learning during the COVID-19 Pandemic. (2020). The World Bank.

Leipzig, D. H. (2021). What is reading? WETA.

Marashi, H., \& Kangani, M. (2018). Using Concept Mapping and Mind Mapping in descriptive and narrative writing Ccasses. Journal of Language and Translation, 8(2), 93-106.

Mills, G. E., Airasian, P., \& Gay, L. R. (2012). Educational research: Competencies for analysis and application. Pearson.

Nurhikmah. (2011). Implementing story mapping strategy to improve the eleventh grade students' reading comprehension of MAN 2 Marabahan. Universitas Negeri Malang.

Nuttal, C. (1996). Teaching reading skills in a foreign language (New Edition). Heinemann.

Parkes, M., Gregory, S., Fletcher, P., \& Adlington, R. (2015). Bringing people together while learning apart: Creating online learning environments to support the needs of rural and remote students. Australian and International Journal of Rural Education., 25(1), 6678.

Rasmitalida, et al. (2020). The perception of primary school teachers of online learning during the COVID-19 pandemic period: A case study in Indonesia. Journal of Ethnic and Cultural Studies, 90-109. 
Sieben, J. M., Heeneman, S., Verheggen, M. M., \& Driessen, E. W. (2021). A concept mapping support the quality of reflections made by undergraduate medical students? A mixed method study. Medical Teacher, 43(4), 388-396.

Syarif, M. (2003). Pemanfaat strategi pemetaan makna untuk meningkatkan kemampuan memahami isi bacaan siswa kelas IV SD Penanggungan 2 kota Malang. Universitas Negeri Malang.

Torre, D. M., Daley, B., Stark-Schweitzer, T., Siddartha, S., Petkova, J., \& Ziebert, M. (2007). A qualitative evaluation of medical student learning with concept maps. Med Teach, 29(9), 949-955.

Yensy, N. A. (2020). Effectiveness of mathematical statistics learning through Whatsapp group media. 